\title{
Real-time PCR to improve the diagnosis of respiratory syncytial virus infection
}

\begin{abstract}
Correspondence
Renate Mentel

Renate.Mentel@uni-

greifswald.de
\end{abstract}

Received 23 April 2003

Accepted 17 July 2003

\author{
R. Mentel, ${ }^{1}$ U. Wegner, ${ }^{1}$ R. Bruns ${ }^{2}$ and L. Gürtler ${ }^{1}$ \\ Friedrich Loeffler Institute of Medical Microbiology ${ }^{1}$ and Department of Paediatrics ${ }^{2}$, University \\ Hospital, Ernst-Moritz-Arndt University Greifswald, Germany
}

\begin{abstract}
Respiratory syncytial virus (RSV) is one of the most important virus respiratory pathogens in infants and young children. A rapid and sensitive diagnosis is essential to focus any outbreak due to this virus. A real-time RT-PCR method was designed using a primer/probe pair from the $\mathrm{F}$ gene. Simultaneously with nested RT-PCR and antigen ELISA, 71 consecutive specimens from hospitalized children with clinical symptoms of acute respiratory distress were evaluated to confirm the incidence of RSV infection. RSV was detected in 25 (35.2 \%) specimens by real-time RT-PCR and in 19 (26.7\%) by nested RT-PCR. The assay was specific for RSV. The procedure offers a rapid and sensitive alternative to conventional RT-PCR. Closed-tube detection eliminates the risk of contamination.
\end{abstract}

\section{INTRODUCTION}

Respiratory syncytial virus (RSV) is the major cause of lower respiratory tract illnesses in young children, so the rapid laboratory diagnosis of RSV is an important component for the management of patients (Thompson et al., 2003; Hall, 2001; Paes, 2003).

There are comprehensive diagnostic tools for the detection of RSV infections. Besides the classical method of virus isolation in tissue culture and antigen detection by ELISA, the technique of nucleic acid amplification allows detection of RSV directly from samples within hours. RT-PCR, nested PCR and semi-nested PCR are used commonly in clinical laboratories (Henkel et al., 1997; Rohwedder et al., 1998; Stockton et al., 1998; Abels et al., 2001; Falsey et al., 2002). PCR involving the synthesis of cDNA followed by two amplification reactions was used successfully in our laboratory and works even with a low number of infectious particles at the time of sample collection due to its high sensitivity. But this method has limitations due to carryover contamination and separate PCR product detection. This report describes the design of a real-time PCR, a simple and sensitive procedure, which was validated with conventional RT-PCR and ELISA.

\section{METHODS}

Specimens. A total of 71 nasopharyngeal aspirates (in Hanks' solution) was collected from children hospitalized during an epidemic outbreak (December 2002 and January 2003). Aliquots of material were made immediately on receipt of specimens and were either tested immediately or stored at $-50^{\circ} \mathrm{C}$ until use.

Abbreviation: RSV, respiratory syncytial virus.
Antigen ELISA. RSV antigen was determined using antigen detection EIA (Virion Serion).

RNA extraction. RNA was extracted from both titrated virus stock prepared in RSV-infected HEp-2 cells and clinical samples using the QIAamp Viral RNA Mini kit (Qiagen), according to the manufacturer's instructions.

Nested RT-PCR. RT-PCR was carried out as nested PCR with primer sets derived from a region located on the F gene of RSV (Rohwedder et al., 1998) with a PE Biosystems GeneAmp 2400 thermocycler (Table 1). First-round amplification (primers F1 and F2) was performed using the Qiagen One-Step RT-PCR kit. Reverse transcription was carried out for $30 \mathrm{~min}$ at $50^{\circ} \mathrm{C}$, followed by an initial PCR activation step for $15 \mathrm{~min}$ at $95^{\circ} \mathrm{C}$ and then 40 cycles for $1 \mathrm{~min}$ at $95^{\circ} \mathrm{C}, 1 \mathrm{~min}$ at $55^{\circ} \mathrm{C}$ and $1 \mathrm{~min}$ at $72{ }^{\circ} \mathrm{C}$. For nested PCR (primers F3 and F4), the profile comprised 5 min at $95^{\circ} \mathrm{C}$, followed by 40 cycles for $1 \mathrm{~min}$ at $95^{\circ} \mathrm{C}, 1 \mathrm{~min}$ at $50^{\circ} \mathrm{C}$ and $2 \mathrm{~min}$ at $72{ }^{\circ} \mathrm{C}$. Expected products of $242 \mathrm{bp}$ were visualized by ethidium bromide staining following electrophoresis on a $3 \%$ agarose gel.

Real-time RT-PCR. Nucleotide sequences were designed using the PRIMER EXPRESS, version 1.0, software (Applied Biosystems) and were directed also to a region located on the F gene of RSV, a highly conserved region in the genome and used successfully as target in our laboratory in the classical PCR method (Table 1). Primers and probe were synthesized by TIB MOLBIOL. The probe was labelled with the $5^{\prime}$ reporter dye 6-carboxy-fluorescein (FAM) and the 3' quencher dye 6-carboxytetramethylrhodamin (TAMRA).

In the two-step RT-PCR, $10 \mu \mathrm{l}$ RNA was transcribed using TaqMan Reverse Transcription reagents (Applied Biosystems) with $2.5 \mu \mathrm{M}$ random hexamers for $10 \mathrm{~min}$ at $25^{\circ} \mathrm{C}, 30 \mathrm{~min}$ at $48^{\circ} \mathrm{C}$ and $5 \mathrm{~min}$ at $95^{\circ} \mathrm{C}$. The cDNA concentration was determined spectrophotometrically at $260 \mathrm{~nm}$. Amplification was carried out with $10 \mu \mathrm{l}$ cDNA in a total reaction volume of $50 \mu \mathrm{l}$, containing $2 \times$ TaqMan Universal PCR Master Mix (Applied Biosystems), 15 pmol of each of the primers and 
Table 1. Sequences of RSV oligonucleotide primers and probe

\begin{tabular}{|c|c|c|c|c|c|}
\hline & Name & Use & Sequence $\left(5^{\prime} \rightarrow 3^{\prime}\right)$ & Region & Position \\
\hline \multicolumn{6}{|c|}{ Conventional RT-PCR ${ }^{\star}$} \\
\hline \multirow[t]{2}{*}{ First-round } & F1 & Forward primer & GTTGGATCTGCAATCGCCAGTGGC & $\mathrm{F}$ & $6090-6113$ \\
\hline & $\mathrm{F} 2$ & Reverse primer & GTACATAGAGGGGATGTGTG & $\mathrm{F}$ & $6609-6628$ \\
\hline \multirow[t]{2}{*}{ Second-round } & F3 & Forward primer & TTAACCAGCAAAGTGTTAGA & $\mathrm{F}$ & $6222-6241$ \\
\hline & $\mathrm{F} 4$ & Reverse primer & TTTGTTATAGGCATATCATTG & $\mathrm{F}$ & $6443-6463$ \\
\hline \multirow[t]{3}{*}{ Real-time RT-PCR $\dagger$} & RS-F1 & Forward primer & AACAGATGTAAGCAGCTCCGTTATC & F & $789-813$ \\
\hline & RS-F2 & Reverse primer & CGATTTTTATTGGATGCTGTACATTT & $\mathrm{F}$ & $878-853$ \\
\hline & RS-F3 & Probe & TGCCATAGCATGACACAATGGCTCCT & $\mathrm{F}$ & $822-847$ \\
\hline
\end{tabular}

*According to the sequences published by Paton et al. (1992).

$\dagger$ GenBank accession no. AF067125.

5 pmol of the TaqMan probe with the following profile: 1 cycle for $2 \mathrm{~min}$ at $50{ }^{\circ} \mathrm{C}$ and $10 \mathrm{~min}$ at $95^{\circ} \mathrm{C}$, followed by 50 cycles for $15 \mathrm{~s}$ at $95^{\circ} \mathrm{C}$ and $1 \mathrm{~min}$ at $60^{\circ} \mathrm{C}$.

In the one-step protocol, $10 \mu \mathrm{l}$ RNA was added to the reaction mixture (TaqMan One-Step RT-PCR Master Mix reagents), containing 15 pmol of each of the primers and 5 pmol of the probe, with the profile: 1 cycle for $30 \mathrm{~min}$ at $48{ }^{\circ} \mathrm{C}$ and $10 \mathrm{~min}$ at $95^{\circ} \mathrm{C}$, followed by 50 cycles for $15 \mathrm{~s}$ at $95^{\circ} \mathrm{C}$ and 1 min at $60{ }^{\circ} \mathrm{C}$.

Real-time RT-PCR was carried out in an I-Cycler iQ Real-Time Detection system, version 3.0 (Bio-Rad).

\section{RESULTS AND DISCUSSION}

For sensitivity, real-time PCR was compared to cell culture by end-point dilutions. The highest dilution for cell culture $\left(\mathrm{TCID}_{50}\right)$ was $10^{5 \cdot 5}$. With the two-step real-time PCR protocol, the end-point was $10^{-7 \cdot 5}$, with a threshold cycle $\left(C_{\mathrm{t}}\right)$ value of $36 \cdot 9$. Tenfold serial dilutions of RSV transcripts were amplified. Results were linear over a range of RSV cDNA concentrations from $1450 \mathrm{ng}$ to $145 \mathrm{pg}$, with a coefficient of correlation of 0.998 (Fig. 1). The performance of triplicate reactions showed high reproducibility, with a $C_{\mathrm{t}}$ deviation of $0 \cdot 046$.

To validate the specificity of the primer design reactions with nucleic acids from adenovirus, herpes simplex virus, cytomegalovirus, varicella-zoster virus, Epstein-Barr virus as well as coxsackie B3 virus and influenza virus as target were performed. Only in the presence of RSV RNA were fluorescent signals observed (data not shown).

Isolates of both RSV subgroups A and B were detected using the real-time PCR protocol. These isolates were identified in a former study to analyse the importance of RSV subtypes and to generate molecular epidemiological data of circulating strains. Subtyping was performed by RT-PCR targeting the $\mathrm{N}$ and $\mathrm{P}$ genes as well as by sequencing using primer pairs located on the RSV G gene, a region that shows the greatest sequence variation between RSV strains (Ilgert et al., 2002).

In previous experiments for the detection of enteroviruses in clinical samples, we observed, in agreement with other authors, that real-time RT-PCR using a described two-step

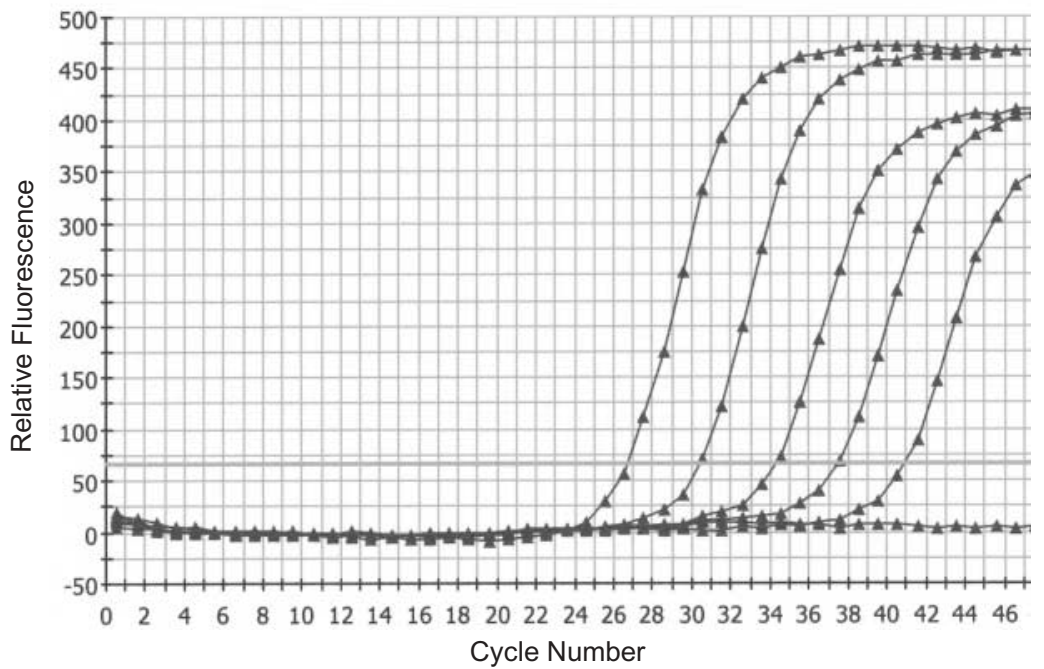

Fig. 1. TaqMan PCR amplification curve of twostep RSV real-time RT-PCR. Tenfold serial dilutions from RSV cDNA (1450 ng to $14.5 \mathrm{pg}$ ) were used, with resulting $C_{t}$ values of $26 \cdot 8,30 \cdot 4,34 \cdot 3$, $37.5,40.9$ and $>45$. The assay was linear over a wide range of concentrations from $1450 \mathrm{ng}$ to $145 \mathrm{pg}$, with a coefficient of correlation of 0.998. 
assay was more sensitive than the one-step assay (Corless et al., 2002; Whiley et al., 2002). Therefore, we used the twostep protocol for RSV detection. Further experiments performed to evaluate the efficiency of the one-step protocol have shown that the resulting $C_{\mathrm{t}}$ values of both protocols were almost coincident (Table 2). Considering the high RSV loads in nasopharyngeal samples, this result indicates sufficient sensitivity of the one-step RSV protocol for respiratory infections, whereas in case of enterovirus infections, low virus loads in cerebrospinal fluid precluded the use of a onestep assay. The continuous method of the one-step assay requires less sample handling and hence is less labourintensive. The advantage of the two-step RT-PCR is that cDNA from the reverse transcription step may be used to amplify nucleic acid of other RNA viruses, which is important for the purposes of differential diagnosis.

To evaluate the developed protocol to detect RSV infections in clinical materials, a total of 71 nasopharyngeal samples was analysed for RSV simultaneously by the designed two-step real-time RT-PCR, nested RT-PCR and antigen ELISA. Of these samples, 25 (35.2\%) were deemed positive for RSV by real-time PCR, $19(26.7 \%)$ by nested RT-PCR and 10 $(14 \cdot 1 \%)$ by antigen ELISA (Table 3 ). It was found that two-step real-time PCR was approximately $25 \%$ more

Table 2. Comparative sensitivity of one-step and two-step realtime RT-PCR

\begin{tabular}{|lcc|}
\hline \multirow{2}{*}{ RSV RNA $(\mathbf{p g})$} & \multicolumn{2}{c|}{$C_{\mathrm{t}}$} \\
\cline { 2 - 3 } & One-step & Two-step \\
\hline $1 \cdot 4 \times 10^{6}$ & $26 \cdot 8$ & $26 \cdot 8$ \\
$1 \cdot 4 \times 10^{5}$ & $30 \cdot 1$ & $30 \cdot 4$ \\
$1 \cdot 4 \times 10^{4}$ & $34 \cdot 0$ & $34 \cdot 3$ \\
$1 \cdot 4 \times 10^{3}$ & $37 \cdot 2$ & $37 \cdot 5$ \\
$1 \cdot 4 \times 10^{2}$ & $42 \cdot 2$ & $40 \cdot 9$ \\
$1 \cdot 4 \times 10^{1}$ & $>45$ & $>45$ \\
\hline
\end{tabular}

Table 3. Simultaneous analysis of samples by two-step real-time RT-PCR, nested RT-PCR and antigen ELISA for detection of $\operatorname{RSV}(n=71)$

Total number of samples positive were: real-time RT-PCR, 25; nested RT-PCR, 19; antigen ELISA, 10. Total number of samples negative, 42.

\begin{tabular}{|c|c|c|c|}
\hline \multicolumn{2}{|c|}{ RT-PCR } & \multirow{2}{*}{$\begin{array}{c}\text { Antigen } \\
\text { ELISA }\end{array}$} & \multirow{2}{*}{$\begin{array}{l}\text { No. of } \\
\text { positive } \\
\text { samples }\end{array}$} \\
\hline Real-time & Nested & & \\
\hline+ & + & + & 7 \\
\hline+ & + & - & 8 \\
\hline+ & - & - & 8 \\
\hline- & + & - & 3 \\
\hline+ & - & + & 2 \\
\hline - & + & + & 1 \\
\hline
\end{tabular}

sensitive than nested RT-PCR and $60 \%$ more sensitive than antigen ELISA. This is in agreement with a report of Gueudin et al. (2003), which was based on real-time RT-PCR using a LightCycler instrument with primers targeting the RSV N gene. It was shown that real-time RT-PCR is able to detect also low level of virus in clinical samples.

Combined with the high specificity and rapid turnaround time, real-time RT-PCR is suitable also for the detection of RSV in adults, particularly in immunocompromised and elderly patients. In these populations, RSV infection can be associated with serious clinical manifestations and death. Diagnosis is difficult due to low virus load in secretions (Thompson et al., 2003; Falsey et al., 2002). Real-time PCR may, therefore, be particularly suitable in the case of reinfection, which is also associated with low virus loads.

Advantages of real-time PCR protocols using primer sets of other regions, as, for example, the $\mathrm{L}$ and $\mathrm{N}$ genes, over conventional procedures for RSV detection in clinical samples have been reported already. A significant improvement over conventional virus detection methods was reached by the LightCycler RT-PCR, with a turnaround time of approximately $2 \mathrm{~h}$ (Whiley et al., 2002). Hu et al. (2003) established a real-time PCR protocol with two primer/probe pairs derived from the $\mathrm{N}$ gene, one targeting RSV subtype A and the other RSV subtype B in a simultaneous reaction. Subgrouping is a comfortable option for further characterization of RSV isolates but is not necessary for basic diagnosis.

The protocol presented here provides a highly sensitive approach for the diagnosis of RSV infections. It is simple and rapid. Furthermore, the omission of post-PCR processing leads to the elimination of false-positive results due to cross contamination. The data obtained confirm the accuracy of the assay. Time to obtain results is possible within 3.5 to $4 \mathrm{~h}$ after receipt of clinical samples. Large-scale samplings can be analysed effectively for RSV screening during an epidemic phase, a very important option for patient management, in particular for the prevention of nosocomial infections.

\section{REFERENCES}

Abels, S., Nadal, D., Stroehle, A. \& Bossart, W. (2001). Reliable detection of respiratory syncytial virus infection in children for adequate hospital infection control management. J Clin Microbiol 39, 3135-3139.

Corless, C. E., Guiver, M., Borrow, R., Edwards-Jones, V., Fox, A. J., Kaczmarski, E. B. \& Mutton, K. J. (2002). Development and evaluation of a real-time RT-PCR for the detection of enterovirus and parechovirus RNA in CSF and throat swab samples. J Med Virol 67, 555-562.

Falsey, A. R., Formica, M. A. \& Walsh, E. E. (2002). Diagnosis of respiratory syncytial virus infection: comparison of reverse transcription-PCR to viral culture and serology in adults with respiratory illness. J Clin Microbiol 40, 817-820.

Gueudin, M., Vabret, A., Petitjean, J., Gouarin, S., Brouard, J. \& Freymuth, F. (2003). Quantification of respiratory syncytial virus RNA in nasal aspirates of children by real-time RT-PCR assay. J Virol Methods 109, 39-45. 
Hall, C. B. (2001). Respiratory syncytial virus and parainfluenza virus. N Engl J Med 344, 1917-1928.

Henkel, J. H., Aberle, S. W., Kundi, W. \& Popow-Kraupp, T. (1997). Improved detection of respiratory syncytial virus in nasal aspirates by seminested RT-PCR. J Med Virol 53, 366-371.

Hu, A., Colella, M., Tam, J. S., Rappaport, R. \& Cheng, S. M. (2003). Simultaneous detection, subgrouping, and quantitation of respiratory syncytial virus A and B by real-time PCR. J Clin Microbiol 41, 149-154.

Ilgert, U., Wegner, U., Bruns, R., Gürtler, L. \& Mentel, R. (2002). Molecular characterization and severity of symptoms associated with respiratory syncytial virus isolates. European Society for Clinical Virology, p. 20 (London, UK, 9-11 January 2002).

Paes, B. A. (2003). Current strategies in the prevention of respiratory syncytial virus disease. Paediatr Respir Rev 4, 21-27.

Paton, A. W., Paton, J. C., Lawrence, A. J., Goldwater, P. N. \& Harris, R. J.
(1992). Rapid detection of respiratory syncytial virus in nasopharyngeal aspirates by reverse transcription and polymerase chain reaction amplification. J Clin Microbiol 30, 901-904.

Rohwedder, A., Keminer, O., Forster, J., Schneider, K., Schneider, E. \& Werchau, H. (1998). Detection of respiratory syncytial virus RNA in blood of neonates by polymerase chain reaction. J Med Virol 54, 320-327.

Stockton, J., Ellis, J. S., Saville, M., Clewley, J. P. \& Zambon, M. C. (1998). Multiplex PCR for typing and subtyping influenza and respiratory syncytial viruses. J Clin Microbiol 36, 2990-2995.

Thompson, W. W., Shay, D. K., Weintraub, E., Brammer, L., Cox, N., Anderson, L. J. \& Fukuda K. (2003). Mortality associated with influenza and respiratory syncytial virus in the United States. JAMA 289, 179-186.

Whiley, D. M., Syrmis, M. W., Mackay, I. M. \& Sloots, T. P. (2002). Detection of human respiratory syncytial virus in respiratory samples by LightCycler reverse transcriptase PCR. J Clin Microbiol 40, 4418-4422. 